\title{
Pertumbuhan UMKM Bakery dan Kue di Kabupaten Bantul Saat Pandemi Covid-19 (Analisis Pada Karakteristik Kewirausahaan Karakteristik Individu dan Aktivitas Wirausaha)
}

\author{
Nuning Kristiania ${ }^{a}$, Ana Mar Atus Sholikhah ${ }^{\text {b }}$ \\ aSTIE YKPN Yogyakarta, kristiani.nuning@gmail.com \\ bTIE YKPN Yogyakarta, annamaratus25@gmail.com
}

\begin{abstract}
A b s t r a k
Studi kewirausahan ini bertujuan untuk mengetahui pertumbuhan ekonomi UMKM pelaku usaha bakery dan kue di kabupaten Bantul, Yogyakarta di masa pandemi Covid-19. Salah satu usaha yang dapat bertahan pada masa pandemi adalah usaha kecil dibidang kuliner. Penelitian ini menggunakan karakteristik kewirausahaan dan karakteristik inividu sebagai dua dari beberapa faktor yang diduga mampu mempengaruhi aktivitas wirausaha. Selanjutnya aktivitas wirausaha diduga mampu mempengaruhi pertumbuhan usaha para pelaku usaha UMKM usaha bakery dan kue di kabupaten Bantul. Sampel yang digunakan dalam studi adalah sebanyak 107 responden dan data diolah dengan menggunakan WarpPLS. Hasil pengolahan data menunjukkan bahwa karakteristik kewirausahaan dan karakteristik individu terbukti berpengaruh terhadap aktivitas kewirausahaan. Sedangkan aktivitas kewirausahaan juga terbukti berpengaruh terhadap pertumbuhan usaha bakery dan kue. Hasil penelitian ini memberikan insight bagi dunia usaha mikro kecil dan menengah di Indonesia antara lain: 1) Pelaku usaha UMKM bakery dan kue terbukti mampu bertahan dari kelesuan ekonomi akibat pandemic Covid-19, 2) Agar usaha dapat tumbuh dan berkembang diperlukan karakteristik kewirasuahaan dan karakteristik personal yang berkualitas dari para pelaku usaha, dan 3) Pelaku usaha UMKM yang mempu menjalankan aktivitas usahanya dengan baik dan maksimal akan berdampak pada pertumbuhan usaha yang berkelanjutan.
\end{abstract}

Kata Kunci: UMKM Bakery dan Kue, Karakteristik Kewirausahaan, Karakteristik Individu, Aktivitas Kewirausahaan, Pertumbuhan Usaha.

\begin{abstract}
A b s tract
This entrepreneurship study aims to determine the economic growth of the MSMEs of Bakery and cake businesses in Bantul Regency, Yogyakarta in the Covid-19 pandemic. One of the businesses that can survive in the pandemic period is a small business in the culinary field. This study uses entrepreneurship characteristics and Vidu as two of several factors that influence entrepreneurial activities. Furthermore, entrepreneurial activity is thought to influence the business growth of the business actors MSMEs Bakery and cakes in Bantul Regency. The sample used in the study was 107 respondents, and data were processed using WarpPLs. Data processing results show that entrepreneurial characteristics and individual characteristics affect entrepreneurial activities. In contrast, entrepreneurial activity is also proven to affect the growth of bakeries and cakes. The results of this study provide insight for the world of small and medium micro-enterprises in Indonesia, among others: 1) Bakery MSMEs business actors and cakes are proven to be able to survive the economic lethargy due to Pandemic Covid-19, 2) so that businesses can grow and develop characteristics of entrepreneurship and characteristics Quality Personal from business actors, and 3) MSMEs business actors who have carried out their business activities properly and maximally will have an impact on sustainable business growth.
\end{abstract}

Keywords: MSMEs Bakery and Cake, Entrepreneurial Characteristics, Individual Characteristics, Entrepreneurship Activities, Business Growth. 


\section{Pendahuluan}

Pada saat ini ada sekitar 58,2 juta usaha mikro, kecil, dan menengah (UMKM) yang ada di Indonesia dan sekitar delapan persen dari total tersebut telah mengikuti perkembangan zaman dengan melakukan go-online dalam pemasaran produk agar mampu bersaing di era 4.0 (www.cnnindonesia.com). Saat ini UMKM menjadi salah satu tumpuan perekonomian Indonesia yang sedang goyah karena dampak pandemi Covid-19. Pandemi Covid-19 yang mulai masuk ke Indonesia awal tahun 2020 berdampak disegala bidang, tidak terkecuali bidang ekonomi. Kebijakan pemerintah untuk membatasi pergerakan masyarakat sempat melumpuhkan aktivitas perekonomian. Akibatnya tidak sedikit perusahaan-perusahaan besar bertumbangan akibat hal ini.

Disisi lain tumbangnya perusahaan-perusahan besar menciptakan pemutusan hubungan kerja (phk) sehingga banyak orang yang beralih profesi. Profesi yang menjadi salah satu pilihan utama korban phk adalah menjadi wirausahawan. Hal ini dapat dibuktikan dengan data Badan Pusat Statistik (BPS) yang menyatakan bahwa terdapat peningkatan jumlah pekerja informal pada tahun 2020 sebesar 1,18 juta orang atau sebesar 2,62\% dibandingkan tahun 2019 (www.bps.go.id). Salah satu pilihan usaha yang paling mudah untuk dilakukan adalah usaha kecil dibidang kuliner. Pilihan usaha dibidang kulinerpun terdapat berbagai macam pilihan, antara lain: 1) usaha bakery rumahan, 2) usaha makanan tradisional, dan 3) warung makan sederhana.

Data menunjukkan di kabupaten Bantul, usaha kue dan bakery merupakan salah satu UMKM dalam industri pengolahan yang berkembang pesat dalam usaha kuliner dalam meningkatkan pertumbuhan ekonomi karena mampu memberikan kontribusi yang besar terhadap masyarakat sekitar seperti merekrut tenaga kerja yang berada di lingkungan tempat produksi sehingga membantu warga untuk meningkatkan kesejahteraan keluarga dan pendapatan keluarganya. Usaha kue dan bakery ini biasa digunakan oleh masyarakat yang sedang ada acara keluarga, keagamaan, pesta pernikahan ataupun meninggalnya seseorang sebagai hampers, buah tangan, snack, dll. Usaha ini termasuk dalam kategori usaha atau bisnis yang berkelanjutan atau bisnis yang akan selalu dibutuhkan oleh manusia dibidang kuliner. Selain itu di Kabupaten Bantul banyak usaha kue dan bakery dari usaha rumahan atau baru mulai merintis usaha tersebut sampai dengan usaha kue dan bakery yang sudah punya toko dan cabang di beberapa wilayah.

Wirausahawan sendiri memiliki arti sebagai seorang individu yang mengambil inisiatif untuk menggabungkan sumber daya dengan cara yang inovatif dan bersedia menanggung risiko dan/atau ketidakpastian untuk bertindak (Hisrich, Peter, dan Shepherd, 2017). Wirausahawan yang tangguh terlihat dari karakteristik-karakteristik yang dimilikinya. Seperti yang dikemukakan oleh Ghina dan Ramadhan (2017) yang menyatakan bahwa karakteristik yang harus dimiliki adalah locus of control, keberanian mengambil risiko, percaya diri, Need for Achievement, dan Innovativeness. Selanjutnya karakteristik individu atau personal juga dipercaya menjadi salah satu faktor penentu keberhasilan usaha. Menurut Hisrich, Peter, dan Shepherd (2017), terdapat tujuh karakteristik individu yang berkaitan dengan keberhasilan usaha yaitu pendidikan, nilai personal, usia, pengalaman kerja, role models dan support systems, dan jaringan. Karakteristik individu 
dapat berasal dari ciri khas bawaan sejak dan lahir dan hasil interaksi individu dengan lingkungannya. Karakteristik kewirausahaan dan karakteristik individu yang kuat akan membentuk sikap mental wirausahawan yang tangguh dalam menjalankan aktivitas usahanya. Pada akhirnya keberhasilan aktivitas usaha diharapkan mampu mendorong pertumbuhan usaha.

Penelitian yang dilakukan oleh Firnalista, Nofialdi, dan Azriani (2020) menemukan bukti bahwa karakteristik berpengaruh terhadap kinerja bisnis UMKM pabrik pengolah gula di kabupaten Agam. Berikut temuan pada riset yang dilakukan oleh Al Farisi (2020) menemukan fakta serupa yaitu terdapat pengaruh karakteristik kewirausahaan atas kesuksesan pasar UMKM di negara Saudi Arabia. Studi sebelumnya menunjukkan bahwa pengalaman kerja dan disiplin diri sebagai karakteristik individu pengusaha berdampak pada kinerja UKM di Nigeria (Ikupolati, et. al, 2017). Temuan serupa juga dinyatakan oleh Hendratmoko (2021) yang menemukan bahwa karakteristik kewirausahaan berpengaruh terhadap UMKM di Indonesia. Studi-studi yang telah dilakukan sebelumnya telah memberikan bukti empiris bahwa karakteristik kewirausahaan dan karakteristik individu mampu mempengaruhi keberhasilan UMKM dan kinerja UMKM yang berdampak akhir pada pertumbuhan UMKM.

Saat krisis ekonomi 1998 terjadi di Indonesia, UMKM terbukti mampu bertahan dari segala kegempuran keterbatasan ekonomi serta daya beli masyarakat. Kondisi serupa dihadapi oleh para pelaku usaha UMKM saat ini. Namun, belum ada bukti yang menyatakan bahwa UMKM mampu bertahan atau bertumbuh saat kelesuan ekonomi akibat pandemi Covid-19. Oleh karena itu, studi ini diperlukan untuk mengetahui apakah UMKM di bidang bakery dan kue masih mampu bertumbuh dengan melihat aktivitas usahanya. Studi ini juga menggunakan karakteristik kewirausahaan dan karakteristik personal untuk mengetahui karakter-karakter wirausahawan yang mampu menjalankan aktivitas usahanya dengan baik dan bertujuan pada pengembangan usaha yang dijalankannya. Hasil penelitian ini selanjutnya bermanfaat untuk memberikan bukti ilmiah atas kondisi usaha yang mampu bertahan dan bertumbuh saat pandemi Covid-19 ini. Sehingga hasil penelitian ini diharapkan dapat memberikan kontribusi untuk memberikan saran atas kebijakan pemerintah, saran bagi pelaku usaha UMKM, serta saran bagi akademisi.

\section{Landasan Teori}

\subsection{Kewirausahaan}

Menurut Diandra dan Azmy (2020) bahwa kewirausahaan merupakan bagian dalam kehidupan bisnis. Sebuah bisnis dikatakan sehat, jika dalam proses bisnisnya terdapat pembelajaran untuk terus berubah dengan cara mengadopsi pembelajaran kewirausahaan dan manajemen. Pendapat lain dinyatakan oleh Subramani (2020) mengemukakan bahwa kewirausahaan adalah tindakan menyeluruh oleh satu atau lebih orang dengan menggunakan keterampilan yang dimilikinyan untuk mengidentifikasi, merebut, dan mengelola peluang ekonomi dan pasar yang belum dijelajahi. Tindakan ini mengandung risiko tetapi juga dapat mendatangkan keuntungan, jika mampu memberikan nilai tambah 
dengan cara melihat, mencari dan membuat perubahan yang diinginkan dalam layanan atau produk. Proses ini membutuhkan kreativitas dan inovasi, berdasarkan proyeksi pemindaian lingkungan.

Selain itu, proses kewirausahaan melibatkan pengelolaan aktivitas seperti: pengelolaan sumberdaya manusia, pengorganisasiaan, pembuatan visi, membangun jaringan, dan pemecahan masalah. Tujuan dari pengelolaan aktivitas ini adalah untuk meningkatkan kemakmuran, supremasi, serta peningkatan status wirausahawan itu sendiri. Pernyataan serupa dikemukakan tentang kewirausahaan oleh Robbins dan Coulter (2016) yang menyatakan bahwa kewirausahaan adalah sebuah proses pemanfaatan usaha dan sarana yang terorganisir untuk memanfaatkan peluang yang bertujuan untuk menciptakan nilai serta bertumbuh dengan cara memenuhi keinginan dan kebutuhan melalui keunggulan inovasi dan keunikan. Pendapat para ahli tersebut mengarah pada kesimpulan bahwa kewirausahaan adalah proses sebuah pembelajaran untuk melakukan tindakan bisnis dengan menggunakan inovasi dan kreativitas yang bertujuan untuk menciptakan bisnis yang bertumbuh dan berkelanjutan.

\subsection{Karakteristik Kewirausahaan}

Karakteristik menggambarkan sifat atau ciri khas individu yang memiliki keunikan personal serta psikologis dan di dalamnya mengandung dimensi nilai serta sikap (Sari, Suwarsinah dan Baga, 2016). Masih menurut Sari, Suwarsinah dan Baga (2016), karakteristik kewirausahaan merupakan faktor kunci pengembangan daya saing ekonomi, pengembangan pola pikir UMKM yang positif, menciptakan sensitifitas terhadap pasar dan daya pikir kreatif serta inovatif. Menurut Ghina dan Ramadhan (2017), terdapat beberapa karakteristik kewirausahaan yang harus miliki seorang wirausahawan, antara lain: locus of control, keberanian mengambil risiko, percaya diri, Need for Achievement, dan Innovativeness.

Locus of control merupakan sebuah keyakinan invidu bahwa apa yang akan dicapainya merupakan hasil dari perilakunya sendiri. Wirausahawan merupakan dituntu menjadi seorang yang mandiri dalam menjalankan usahanya. Keberhasilan dan kegagalan usaha merupakan hasil dari usahanya sendiri. Oleh karena itu, seorang wirausawahan dituntun memiliki Locus of control dalam dirinya. Salah satu hal yang menjadi tantangan bagi pengusaha adalah adanya risiko yang dihadapinya.

Risiko merupakan sebuah kondisi ketidakpastian yang dapat terjadi ketika semua aktivitas dilakukan. Ketidakpastian dalam bisnis dapat diartikan sebagai kondisi untung atau rugi yang akan didapatkan dari hasil kegiatan usaha yang dijalankannya. Wirusahawaan saat ini dituntut untuk berani bertanggungjawab serta berani mengambil risiko untuk pengembangan dan kelangsungan hidupnya dengan tujuan mendapatkan hasil yang sesuai (Hisrich, Peter, dan Shepherd, 2017). Jika seorang wirausahawaan memiliki kecenderungan untuk berani mengambil risko, maka ia akan memiliki kemampuan untuk dapat melihat peluang serta manfaat yang lebih luas bagi organisasi (Farrukh et al., 2017). Percaya diri adalah sebuah keyakinan individu bahwa dirinya mampu mencari solusi dan mengatasi masalah yang dihadapinya. Kepercayaan diri seorang wirausahawan tercermin dari cara mengatasi masalah yang dihadapi saat melakukan kegiatan usaha. Sedangkan, 
Need for Achievement merupakan keinginan untuk mendapatkan kesuksesan dan mencapai prestasi di bidang tertentu. Seorang wirausahawan diharapkan memiliki Need for Achievement untuk pengembangan bisnisnya. Need for Achievement merupakan bagian dari motivasi, motivasi sendiri adalah rangkaian set sikap dan nilai yang mempengaruhi individu untuk mencapai tujuan spesifik dalam hidupnya (Zainal et.al, 2018). Motivasi inilah yang akan membentuk dorongan dan keinginan individu untuk berusaha mewujudkan rencana-rencana yang dimilikinya. Motivasi seorang wirausahawan mengacu pada dorongan yang dimiliki pengusaha untuk mengambil tindakan yang bertujuan untuk membangun bisnisnya (Hisrich, Peter, dan Shepherd, 2017).

Toleransi terhadap ambiguitas adalah kemampuan merespon secara positif untuk situasisituasi ambigu yang biasa dihadapi oleh wirausahawan. Karakteristik yang terakhir adalah Innovativeness, seorang wirausahawan dituntut memiliki daya kreativitas dan inovasi yang digunakan untuk menghasilkaan nilai akhir yang bermanfaat bagi pengembangan bisnisnya. Dalam studi ini akan berfokus pada karakteristik kewirausahaan pada indikator keberanian mengambil risiko dan Need for Achievement.

\subsection{Karakteristik Individu}

Karakteristik individu berkaitan dengan sifat dan ciri khas yang membedakan satu individu dengan individu lainnya. Sifat dan ciri khas inilah yang nantinya menjadi faktor pendorong individu untuk menampilkan karakternya dalam bersikap dan berinteraksi di kehidupan sosialnya. Pembentuk karakter individu dapat berasal dari karakter bawaan sejak lahir dan karakter yang didapatkan saat individu berinteraksi di lingkungannya. Menurut Hisrich, Peter, dan Shepherd (2017), karakteristik individu yang mempengaruhi keberhasilan usaha adalah pendidikan, nilai personal, usia, pengalaman kerja, role models dan support systems, dan jaringan. Dalam penelitian ini difokuskan pada usia, pendidikan dan pengalaman kerja.

Faktor usia berkaitan dengan kematangan wirausahawan dalam menjalankan usahanya. Tingkat kedewasaan diperlukan untuk kebijaksanaan dalam mengambil keputusan. Salah satu faktor yang mempengaruhi kedewasaan individu adalah usia. Semakin bertambahnya usia diharapkan mampu memberikan kedewasaan dalam berpikir. Pendidikan termasuk pelatihan berguna untuk menambah pengetahuan bagi pelaku usaha. Wirausaha yang memiliki bekal pendidikan yang mumpuni akan mampu menganalisis kondisi usaha yang berjalan dan berguna bagi pengembangan usaha. Pengalaman kerja yang dimaksud dalam studi ini adalah pengalaman usaha yang dijalankan wirausahawan. Pengalamaan usaha berkaitan dengan lamanya usaha berjalan serta kemampuan wirausahawan. Selain itu, pengalaman usaha juga dapat dilihat dari kemampuan bertahan ketika mengahadapi kesulitan-kesulitan usaha, sehingga terhindar dari kegagalan.

\subsection{Aktivitas Wirausaha}

Aktivitas wirausaha adalah kegiatan yang dijalankan wirausahawan untuk sebagai proses bisnis yang dilakukannya. Indikator yang digunakan dalam aktivitas wirausaha adalah produksi dan daya saing. Atmaja (2016), menyatakan bahwa aktivitas wirausaha 
merupakan faktor pembentuk sikap, perilaku dan pola pikir seorang wirausahawan. Ketiga faktor ini dapat terwujud dengan adanya asset sumber daya manusia yang dimiliki. Asset sumberdaya manusia digunakan untuk mempersiapkan dirinya untuk memulai sebuah usaha. Wirausahawan hakekatnya adalah seseorang yang awal mulanya bekerja secara mandiri. Sehingga dalam menjalakan aktitivas usahanya, seorang wirausahawan melakukan proses produksi secara mandiri. Wijaya et.al (2020), menyatakan bahwa produksi adalah sebuah kegiatan untuk penciptaaan barang dan jasa dengan memberikan nilai tambah bagi perusahaan. Oleh karena itu, kegiatan produksi tidak hanya fokus pada proses pengubahan dari bahan mentah menjadi barang jadi saja. Pada akhirnya, hasil dari proses produksi akan menghasilkan produk atau jasa yang memiliki nilai manfaat yang akan ditawarkan kepada pembeli. Daya saing merupakan bagian dari penciptaan nilai dilingkup usaha. Nilai yang ditampilkan merupakan manfaat yang ditawarkan bagi konsumen dan menjadi faktor pembeda dengan produk pesaing.

\subsection{Pertumbuhan Usaha}

Saat ini, hampir semua perusahaan dituntut harus berorintasi pada pertumbuhan, Pertumbuhan menjadi faktor penting dalam keberlanjutan bisnis. Orientasi untuk terus tumbuh tidak hanya dilakukan oleh perusahaan dengan skala besar akan tetapi UMKM juga mulai berfikir untuk terus maju dan berlanjut. Menurut Hisrich, Peter, dan Shepherd (2017) terdapat dua perbedaan laju pertunbuhan antara perusahaan yang dikelola secara tradisional dan yang dikekola dengan konsep kewirausahaan, yaitu: 1) perusahaan yang dikelola secara tradisional akan melakukan pertumbuhan yang lambat dan stabil dan 2) perusahaan yang dikeloa dengan konsep kewirausahaan cenderung memiliki keinginan untuk lebih cepat memperluas perusahaan.

Indikator keberhasilan sebuah usaha tidak hanya pada kemampuan menghasilkan laba saja. Sebuah usaha yang baik adalah usaha yang mampu bertumbuh dan berkembang. Pertumbuhan usaha juga dapat diartikan sebagai bentuk usaha dari wirausahaan untuk mengembangkan usahanya agar mencapai satu titik kesuksesan. Menurut Sarwoko dan Frisdiantara (2016), kajian kinerja usaha kecil dan menengah dapat diklasifikasikan menjadi dua kelompok yang fokus pada aspek pribadi dan organisasi. Aspek kepribadian, seperti karakteristik individu, demografi, dan kompetensi. Sedangkan kajian aspek organisasi meliputi sumber daya organisasi, kompetensi perusahaan, budaya organisasi, dan struktur. Kinerja inilah yang nantinya akan menjadi penentu apakah sebuah usaha dapat tumbuh dan berkembang atau justru mengalami penurunan. Lee dan Tsang dalam Sarwoko dan Frisdiantara (2016), menyatakan bahwa terdapat tiga indikator pertumbuhan usaha yaitu: penjualan, keuntungan dan capital. Dengan kata lain, sebuah usaha dapat dikatakan tumbuh dan berkembang dengan dari: 1) jumlah produksi yang dapat dijual (omset penjualan); 2) pertumbuhan jumlah tenaga kerja; dan 3) pertumbuhan pelanggan yang data diamati dari pergerakan market share. Pertumbuhan usaha akan tercapai jika wirausawahan terdorong meningkatkan kemampuannya untuk terus belajar membangun usahanya. Rasa ketidakpuasan dengan posisi apa yang telah dicapai saat ini juga akan membuat wirausahawan untuk begerak maju mencari sesuatu yang baru untuk 
pengembangan usahanya. Sebuah usaha yang terus bertumbuh akan mencapai sebuah keberlanjutan usaha di masa yang akan datang.

\section{Kerangka penelitian}

Kerangka penelitian adalah kerangka yang menjelaskan alur berfikir yang digunakan untuk menunjukkan hubungan variabel bebas dengan variabel terikat. Berdasarkan pemaparan landasan teori di atas, maka kerangka berfikir dalam penelitian ini adalah sebagai berikut:

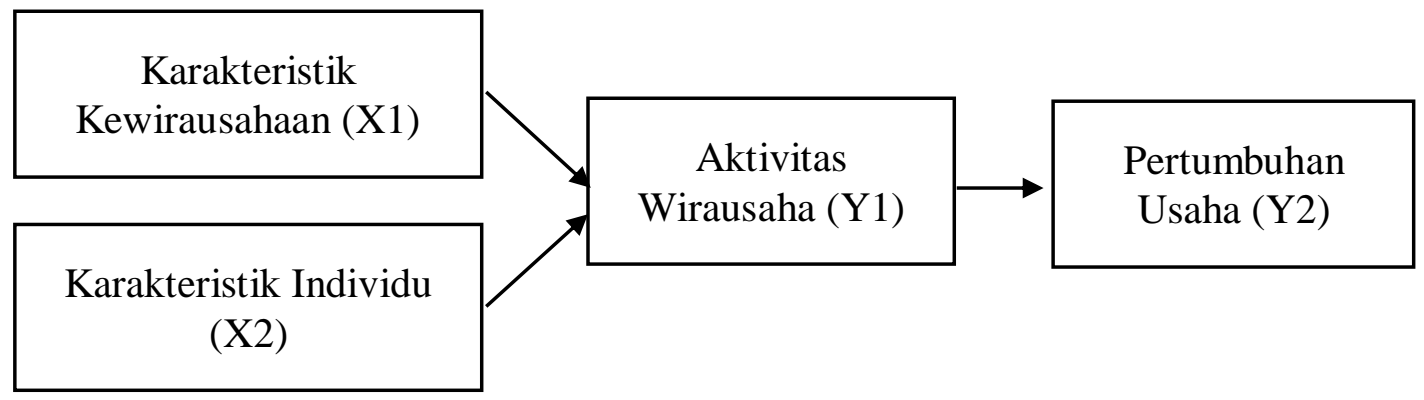

Gambar 1 Kerangka Penelitian

Hubungan antara variabel endogen dan variable eksogen di atas dapat dijelaskan kembali melalui hipotesis yang diajukan. Berikut ini adalah hipotesis atau dugaan sementara dari kerangka berfikir yang diajukan dalam penelitian ini:

Karakteristik kewirausahaan merupakan ciri-ciri yang dimiliki oleh seorang untuk dapat menjadi seorang wirausahawan yang berhasil. Seseorang yang memiliki karakteristik kewirausahaan yang kuat diduga mampu membuat dirinya berhasil daalam menjalankan aktivitas usahanya. Dalam penelitian yang dilakukan oleh Sari et al., (2021) ditemukan bukti bahwa karakteristik kewirausahaan berpengaruh signifikan dan positif terhadap aktivitas wirausaha usaha pengelolaan swah di Sawangan, Depok. Begitu juga dengan penilitian yang dilakukan oleh Firnalista, Nofialdi, dan Azriani (2020); Al Farisi (2020) juga mendapatkan bukti yang sama bahwa terdapat pengaruh antara karakteristik kewirausahaan dan aktivitas wirasuaha. Pemaparan tersebut mengerucut pada pengajuan hipotesis pertama, yaitu:

H1: terdapat pengaruh positif karakteristik kewirausahaan terhadap aktivitas wirausaha UMKM kue dan bakery di Kabupaten Bantul.

Karakteristik kepribadian merupakan salah satu faktor penentu kinerja usaha. Seorang yang memiliki karakteristik kepribadian yang kuat dan positif akan memiliki motivasi yang kuat dalam menjalankan aktivitas wirausahanya. Temuan studi yang dilakukan oleh Sari, Septiowati dan Saputri (2021) menunjukkan bukti bahwa karakteristik personal berpengaruh positif dan signifikan terhadap aktivitas wirausaha. Temuan serupa juga didapatkan dari hasil studi yang dilakukan oleh (Ikupolati, et. al, 2017) dan Hendramotko (2021) yang membuktikan bahwa terdapat pengaruh karakteristik personal atau invividu 
dengan aktivitas wirasuaha. Dugaan adanya pengaruh kedua variabel tersebut menjadi dasar pengajuan hipotesis kedua, yaitu:

H2: terdapat pengaruh positif karakteristik individu terhadap aktivitas wirausaha UMKM kue dan bakery di Kabupaten Bantul

Aktivitas wirausaha adalah proses kegiatan yang dilakukan oleh wirausahawan dalam menjalankan usahanya. Jika usaha tersebut mampu bersaing dengan kompetitornya dan memiliki sistem produksi yang baik, maka pertumbuhan usaha akan dicapainya. Riset yang dilakukan oleh Sari, Septiowati dan Saputri (2021) memberikan bukti bahwa aktivitas wirausaha berpengaruh signifikan dan positif tehadap pertumbuhan usaha UMKM. Berdasarkan uraian di atas, maka hipotesis ketiga yang diajukan adalah sebagai berikut:

H3: terdapat pengaruh positif aktivitas wirausaha terhadap pertumbuhan usaha UMKM kue dan bakery di Kabupaten Bantul.

\section{Metode}

\subsection{Jenis dan Sumber Data}

Data yang digunakan dalam penelitian ini meliputi data primer dan sekunder. Sumber data utama mencakup semua metode pengumpulan data dari aslinya mengumpulkan khusus untuk tujuan penelitian. Data primer didapatkan dengan metode survei melalui penyebaran kuesioner. Penyebaran kuesioner dilakukan dengan mendatangi langsung pelaku usaha UMKM bakery dan kue di kabupaten Bantul, Daerah Istimewa Yogyakarta. Kuesioner penelitian terdiri dari butir-butir pertanyaan yang merupakan indikator dari karakteristik kewirausahaan, karakteristik individu, aktivitas wirausaha dan pertumbuhan usaha. Data primer diperlukan untuk mencari data-data statistik maupun studi-studi, literatur-literatur dan bukti-bukti ilmiah lainnya yang dilakukan oleh para ahli dari berbagai sumber.

\subsection{Populasi dan Sampel}

Populasi pada penelitian ini yaitu seluruh pelaku usaha UMKM di bidang bakery dan kue di Kabupaten Bantul. Metode pengambilan sampel yang digunakan dalam studi adalah purposive sampling. Metode ini memungkinkan pengambilan sampel berdasarkan pertimbangan atau kriteria tertentu. Pertimbangan yang disyaratkan dalam penelitian ini adalah pelaku usaha UMKM di bidang bakery dan kue di kabupaten Bantul yang mudah ditemui. Dari hasil pengumpulan data didapatkan data sampel sebanyak 107 responden.

\subsection{Metode Analisis Data}

Data kemudian diproses dan diolah menggunakan teknik statistik multivariat PLS (Partial Least Square) dengan menggunakan alat analisi WarpPLS. Menurut Sholihin dan dan Ratmono (2021), PLS merupakan sebuah pendekatan dengan menggunakan model kausal yang bertuuan untuk memaksimumkan variasi dari variabel laten criterion yang dapat dijelaskan variabel laten prediktor (2021). Sedangkan WarpPLS adalah sebuah perangkat lunak statistik yang dapat digunakan untuk mengolah data mengidentifikasi hubungan 
nonlinier antar variabel laten dan mengkoreksi nilai koefesien jalur berdasar hubungan tersebut (Sholihin dan dan Ratmono, 2021).

Studi ini juga menggunakan uji reliabilitas dan uji validitas yang dilakukan dengan menggunakan outer model. Tujuan dari kedua uji ini adalah untuk mengukur kualitas data primer yang didapatkan. Jika data primer yang dikumpulan melalui kuesioner tersebut memenuhi syarat yang ditelah ditentukan oleh uji reliabilitas dan uji validitas, maka data dapat digunakan untuk proses pengujian berikutnya. Langkah selanjutnya adalah melakukan uji inner model. Uji ini terdari dari yaitu: uji kecocokan model (uji fit) dan nilai $\mathrm{R}$-square $\left(\mathrm{R}^{2}\right)$. Nilai $\mathrm{R}$-square $\left(\mathrm{R}^{2}\right)$ atau dalam statistik juga dikenal sebagai nilai koefisien determinasi digunakan untuk mengetahui seberapa besar variasi variabel eksogen mampu menjelaskan varibel endogen. Pengujian terakhir yang dilakukan adalah pengujian hipotesis. Pengujian hipotesis dilakukan dengan cara analisis jalur (path analysis) atas model yang telah dibuat.

\section{Hasil Analisis dan Pembahasan}

\subsection{Karakteristik Responden}

Dalam penyebaran data primer melalui kuesioner, beberapa pertanyaan ditunjukkan untuk mengetahui karakteristik responden yang digunakan sebagai sampel dalam penelitian ini. Dengan total responden sebanyak 107 orang, berikut adalah hasil dari karakteristik responden yang didapatkan: 1) karakteristik berdasarkan jenis kelamin: pria (26 orang) dan wanita (81 orang); 2) karakteristik berdasarkan usia: 21-25 tahun (25 orang), 26-30 tahun (17 orang), 31-35 tahun (9 orang), 36-40 tahun (17 orang), 41-45 tahun (10 orang), 46-49 tahun (6 orang), dan lebih dari 50 tahun (23 orang); 3) karakteristik berdasarkan lamanya usaha: kurang dari 1 tahun (6 orang), 1-10 tahun (76 orang), 11-20 tahun (12 orang), 21-30 tahun (12 orang), dan lebih dari 30 tahun (1 orang); 4) karakteristik berdasarkan jumlah karyawan yang dimiliki pelaku usaha: 1-4 karyawan (79 orang), 510 karyawan (16 orang), dan lebih dari 10 karyawan (12 orang); 5) karakteristik berdasarkan asset yang dimiliki: kurang dari Rp50.000.000 juta (62 orang), Rp50.000.000-Rp149.000.000 (22 orang), Rp150.000.000-Rp249.000.000 (7 orang), dan lebih dari Rp250.000.000 (15 orang).

Berdasarkan hasil dari karakteristik responden, maka dapat disimpulkan. Pertama, pelaku usaha UMKM bakery dan kue di kabupaten Bantul didominasi oleh wanita sebanyak 81 orang. Tidak sedikit wanita yang memiliki hobi membuat kue, roti serta makanan tradisional. Hobi inilah yang nantinya menjadi cikal bakal berdirinya usaha kecil. Itulah sebabnya jumlah pelaku usaha dibidang ini didominasi oleh wanita. Kedua, dominasi pelaku usaha untuk karakteristik usia didominasi oleh usia 21-25 tahun sebanyak 25 orang lalu diikuti oleh usia lebih dari 50 tahun sebanyak 23 orang. Hasil ini dapat mencerminkan dua hal, yaitu: a) pemilik usaha bakery dan kue memulai usahanya pada usia matang dan b) usia tua (lebih dari 50 tahun) tidak menjadi penghalang bagi pelaku usaha bakery dan kue untuk terus menjalankan usahanya. Ketiga, lamanya usaha yang dijalankan didominasi oleh range 1-10 tahun. Hal ini membuktikan bahwa usaha bakery dan kue mampu mempertahankan bisnisnya pada segala kondisi. Pernyataan ini 
dapat dikuatkan dengan dominasi lama usaha berikunya yaitu: 11-20 tahun serta 21-30 tahun yang sama-sama menunjukkan nilai sebesar 12 orang pelaku usaha. Keempat, karakteristik jumlah karyawan didominasi oleh sejumlah 1-4 orang sebanyak 79 pelaku usaha. Dari hasil ini dapat diambil kesimpulan bahwa pelaku usaha bakery dan kue di kabupaten Bantul masih didominasi oleh usaha rumahan yang belum memerlukan tenaga kerja dengan jumlah banyak. Kelima, karakteristik yang terakhir adalah berdasarkan asset yang dimiliki. Hasil pengolahan data menunjukkan bahwa asset senilai kurang dari Rp50.000.000 mendominasi yaitu sebanyak 62 orang pelaku usaha. Sejalan dengan hasil dari karaketristik jumlah karyawan, hasil dari asset yang dimilikinyapu menunjukkan bahwa pelaku usaha bakery dan kue di Bantul mayoritas adalah pelaku usaha rumahan dalam skala mikro yang memiliki asset kurang dari Rp50.000.000.

\subsection{Hasil Evaluasi Model (Outer Model)}

Hasil evaluasi model (outer model) dibagi menjadi tiga kategori yaitu uji validitas konvergen (convergent validity), uji vaiditas diskriminan (discriminant validity), dan uji reliabilitas (reliability). Berikut ini adalah hasil olah data.

\subsubsection{Hasil Uji Validitas Konvergen}

Validititas konvergen digunakan untuk mengukur besarnya korelasi antara konstruk dengan variabel laten. Evaluasi convergent validity dilihat dari masing-masing item reliabilitas yang didapatkan dari nilai standardized loading factor. Standardized loading factor memiliki interpretasi besarnya korelasi antar indikator yang terdiri dari item-item pernyataan/pernyataan dengan konstruknya. Kriteria yang harus dipenuhi untuk menghasilkan pengujian validitas konvergen yaitu menggunakan factor loading dengan syarat nilai loading harus diatas 0.7 dan nilai p signifikan kurang dari 0.05. tetapi dalam buku Sholihin dan Ratmono (2021) mengatakan bahwa syarat loading di atas 0.7 sering tidak terpenuhi. Oleh karena itu nilai loading antara $0.4-0.7$ dapat dipertimbangkan, namun untuk mempertimbangkan nilai loading tersebut harus melakukan analisis lagi yaitu menghapus indikator reflektif dan atau mempertahankan indikator reflektif. Kemudian jika nilai loading kurang dari 0.4 harus dihapus dari model. Berikut adalah hasil dari pengolahan data uji validitas konvergen:

\section{Tabel 1}

Uji Validitas Konvergen Karakteristik Kewirausahaan

\begin{tabular}{|c|c|c|c|}
\hline Indikator & X1 & P value & Keterangan \\
\hline KKM1 & 0.553 & $<0.001$ & Valid \\
\hline KKM2 & 0.492 & $<0.001$ & Valid \\
\hline KKM3 & 0.520 & $<0.001$ & Valid \\
\hline KKR1 & 0.576 & $<0.001$ & Valid \\
\hline KKR2 & 0.457 & $<0.001$ & Valid \\
\hline KKI1 & 0.576 & $<0.001$ & Valid \\
\hline KKI2 & 0.682 & $<0.001$ & Valid \\
\hline KKI3 & 0.603 & $<0.001$ & Valid \\
\hline
\end{tabular}

Sumber: data primer, diolah (2021) 
Tabel 2

Uji Validitas Konvergen Karakteristik Kewirausahaan

\begin{tabular}{|c|c|c|c|}
\hline Indikator & X2 & P value & Keterangan \\
\hline KIU1 & 0.566 & $<0.001$ & Valid \\
\hline KIU2 & 0.505 & $<0.001$ & Valid \\
\hline KIP1 & 0.669 & $<0.001$ & Valid \\
\hline KIP2 & 0.607 & $<0.001$ & Valid \\
\hline KIPd1 & 0.526 & $<0.001$ & Valid \\
\hline KIPd2 & 0.454 & $<0.001$ & Valid \\
\hline
\end{tabular}

Sumber: data primer, diolah (2021)

Tabel 3

Uji Validitas Konvergen Aktivitas Wirausaha

\begin{tabular}{|c|c|c|c|}
\hline Indikator & Y1 & P value & Keterangan \\
\hline AWDS1 & 0.689 & $<0.001$ & Valid \\
\hline AWDS2 & 0.476 & $<0.001$ & Valid \\
\hline AWPs1 & 0.670 & $<0.001$ & Valid \\
\hline AWPs2 & 0.712 & $<0.001$ & Valid \\
\hline AWPs1 & 0.678 & $<0.001$ & Valid \\
\hline
\end{tabular}

Sumber: data primer, diolah (2021)

Tabel 4

Uji Validitas Konvergen Pertumbuhan Usaha

\begin{tabular}{|c|c|c|c|}
\hline Indikator & Y2 & P Value & Keterangan \\
\hline PUPe1 & 0.507 & $<0.001$ & Valid \\
\hline PUPe2 & 0.741 & $<0.001$ & Valid \\
\hline PUPe3 & 0.809 & $<0.001$ & Valid \\
\hline PUPe4 & 0.859 & $<0.001$ & Valid \\
\hline
\end{tabular}

Sumber: data primer, diolah (2021)

Hasil pengujian validitas konvergen untuk setiap indikator keempat variabel yang digunakan menunjukkan kisaran nilai sebesar 0,4-0,8. Maka, dapat diambil kesimpulan bahwa setiap butir pertanyaan yang merupakan indikator keempat variabel yang digunakan adalah valid.

\subsubsection{Hasil Uji Validitas Diskriminan}

Validitas diskriminan terjadi jika dua instrumen yang berbeda mengukur dua konstruk yang diprediksi tidak berkolerasi menghasilkan skor yang memang tidak berkorelasi. Berikut ini adalah hasil dari pengujian validitas diskriman.

Tabel 5

Uji Validitas Diskriminan Karakteristik Kewirausahaan

\begin{tabular}{|c|c|c|c|c|c|c|}
\hline \multirow{2}{*}{ Indikator } & \multirow{2}{*}{ Nilai Loading } & & \multicolumn{3}{|c|}{ Konstruk lainnya } & \multirow{2}{*}{ Keterangan } \\
\cline { 4 - 6 } & & & X2 & Y1 & Y2 & \\
\hline KKM1 & 0.553 & $>$ & 0.297 & 0.195 & 0.115 & Memenuhi \\
\hline KKM3 & 0.492 & $>$ & 0.147 & -0.021 & 0.116 & Memenuhi \\
\hline KKM4 & 0.520 & $>$ & 0.300 & 0.255 & 0.058 & Memenuhi \\
\hline KKR1 & 0.576 & $>$ & 0.101 & 0.279 & 0.212 & Memenuhi \\
\hline KKR3 & 0.457 & $>$ & 0.269 & 0.228 & 0.112 & Memenuhi \\
\hline KKI1 & 0.576 & $>$ & 0.218 & 0.272 & 0.268 & Memenuhi \\
\hline KKI3 & 0.682 & $>$ & 0.311 & 0.348 & 0.141 & Memenuhi \\
\hline KKI4 & 0.603 & $>$ & 0.223 & 0.330 & -0.002 & Memenuhi \\
\hline
\end{tabular}

Sumber: data primer, diolah (2021) 
Tabel 6

Uji Validitas Diskriminan Karakteristik Individu

\begin{tabular}{|c|c|c|c|c|c|c|}
\hline \multirow{2}{*}{ Indikator } & \multirow{2}{*}{$\begin{array}{c}\text { Nilai } \\
\text { Loading }\end{array}$} & & \multicolumn{3}{|c|}{ Konstruk lainnya } & \multirow{2}{*}{ Keterangan } \\
\cline { 4 - 6 } & & X1 & Y1 & Y2 & \\
\hline KIU1 & 0.566 & $>$ & 0.241 & 0.446 & 0.147 & Memenuhi \\
\hline KIU2 & 0.505 & $>$ & 0.128 & 0.096 & -0.027 & Memenuhi \\
\hline KIP1 & 0.669 & $>$ & 0.439 & 0.362 & 0.225 & Memenuhi \\
\hline KIP2 & 0.607 & $>$ & 0.345 & 0.594 & 0.326 & Memenuhi \\
\hline KIPd1 & 0.526 & $>$ & 0.201 & 0.229 & 0.278 & Memenuhi \\
\hline KIPd2 & 0.454 & $>$ & 0.037 & 0.133 & 0.201 & Memenuhi \\
\hline
\end{tabular}

Sumber: data primer, diolah (2021)

Tabel 7

Uji Validitas Diskriminan Aktivitas Wirausaha

\begin{tabular}{|c|c|c|c|c|c|c|}
\hline \multirow{2}{*}{ Indikator } & \multirow{2}{*}{$\begin{array}{c}\text { Nilai } \\
\text { Loading }\end{array}$} & & \multicolumn{3}{|c|}{ Konstruk lainnya } & \multirow{2}{*}{ Keterangan } \\
\cline { 4 - 6 } & & & $\mathbf{X 1}$ & $\mathbf{X 2}$ & Y2 & \\
\hline ADWS1 & 0.689 & $>$ & 0.344 & 0.512 & 0.267 & Memenuhi \\
\hline ADWS2 & 0.476 & $>$ & 0.071 & 0.200 & -0.052 & Memenuhi \\
\hline ADPs1 & 0.670 & $>$ & 0.254 & 0.357 & 0.178 & Memenuhi \\
\hline ADPs2 & 0.712 & $>$ & 0.357 & 0.363 & 0.259 & Memenuhi \\
\hline ADPs3 & 0.678 & $>$ & 0.337 & 0.370 & 0.174 & Memenuhi \\
\hline
\end{tabular}

Sumber: data primer, diolah (2021)

Tabel 8

Uji Validitas Diskriminan Pertumbuhan Usaha

\begin{tabular}{|c|c|c|c|c|c|c|}
\hline \multirow{2}{*}{ Indikator } & \multirow{2}{*}{$\begin{array}{c}\text { Nilai } \\
\text { Loading }\end{array}$} & & \multicolumn{3}{|c|}{ Konstruk lainnya } & \multirow{2}{*}{ Keterangan } \\
\cline { 4 - 6 } & & $\mathbf{X 1}$ & $\mathbf{X 2}$ & Y1 & \\
\hline PUPe1 & 0.507 & $>$ & 0.286 & 0.151 & 0.257 & Memenuhi \\
\hline PUPe2 & 0.741 & $>$ & 0.008 & 0.277 & 0.133 & Memenuhi \\
\hline PUPe3 & 0.809 & $>$ & 0.196 & 0.268 & 0.141 & Memenuhi \\
\hline PUPe4 & 0.859 & $>$ & 0.177 & 0.312 & 0.216 & Memenuhi \\
\hline
\end{tabular}

Sumber: data primer, diolah (2021)

Validitas diskriminasi dihitung dari cross loading dengan membandingkan nilai yang ada bahwa nilai loading ke konstruk lain (cross-loading) bernilai lebih rendah daripada nilai loading ke konstruk variabel (Sholihin dan Ratmono, 2021). Metode lainnya dihitung dengan membandingkan akar AVE (average variance extracted) untuk setiap konstruk dengan korelasi antara konstruk dengan konstruk lainnya dalam model (Abdillah dan Hartono, 2016). Berdasarkan hasil pengujian di atas, maka dapat diambil kesimpulan bahwa semua indikator yang digunakan telah memenuhi persyaratan uji validitas diskriminan.

\subsubsection{Uji Reliabilitas}

Hasil uji reliabilitas diukur dengan menggunakan dua kriteria yaitu composite reliability coefficients dan cronbach's alpha coefficients. Hasil pengolahan data dengan WarpPLS 7.0. 
Tabel 9

Uji Reliabilitas

\begin{tabular}{|c|c|c|c|}
\hline Indikator & $\begin{array}{c}\text { Composite Reliability } \\
\text { Coefficients }\end{array}$ & $\begin{array}{c}\text { Cronbach's Alpha } \\
\text { Coefficients }\end{array}$ & Simpulan \\
\hline KK (X1) & 0.8 & 0.7 & Reliabel \\
\hline KI (X2) & 0.7 & 0.6 & Reliabel \\
\hline AW (Y1) & 0.8 & 0.7 & Reliabel \\
\hline PE (Y2) & 0.8 & 0.7 & Reliabel \\
\hline
\end{tabular}

Sumber: data primer, diolah (2021)

Irwan dan Adam (2015) menyatakan bahwa nilai Composite Reliability sebesar 0,8 atau lebih memiliki arti bahwa konstruk memiliki tingkat validitas yang tinggi. Sedangkan nilai Composite Reliability sebesar 0,6 atau lebih memiliki tingkat reliabilitas yang cukup. Menurut Sujarweni (2014), Kriteria yang digunakan untuk uji reliabilitas dengan menggunakan Cronbach's Alpha Coefficients adalah sebagai berikut: 1) jika nilai Cronbach's Alpha sebesar 0,60 atau lebih, maka konstruk yang digunakan reliabel atau konsisten, dan 2) jika nilai Cronbach's Alpha sebesar kurang dari 0,60, maka konstruk yang digunakan tidak realiabel atau tidak konsisten. Hasil pengujian dalam penelitian ini menunjukkan nilai Composite Reliability untuk semua konstruk yang diajukan berada di nilai 0,7 dan 0.8 , maka dapat dinyatakan semua konstruk yang diajukan reliabel. Nilai Cronbach's Alpha untuk pengujian ini juga menunjukkan angka 0,6 dan 0,7, maka dapat dinyatakan bahwa semua konstruk yang diajukan dalam penelitian ini adalah reliabel.

\subsection{Hasil Evaluasi Model (Inner Model)}

Dalam Inner Model yaitu uji kecocokan model (goodness fit model). Dalam uji kecocokan model ini menampilkan hasil tiga indikator fit meliputi APC (Average Path Coefficient), ARS (Average R-Square), AVIF (Average Variance Inflation Factor), dan nilai R square $\left(\mathrm{R}^{2}\right)$. Berikut ini hasil evaluasi model dengan inner model:

\subsubsection{Hasil Output Goodness Fit Model}

\section{Tabel 10}

Goodness Fit Model

\begin{tabular}{|c|c|c|c|c|}
\hline & Indeks & p-value & Kriteria & keterangan \\
\hline APC & 0.316 & $\mathrm{P}<0.001$ & $\mathrm{P}<0.05$ & Signifikan \\
\hline ARS & 0.211 & $\mathrm{P}<0.001$ & $\mathrm{P}<0.05$ & Signifikan \\
\hline AVIF & 1.212 Good if $<5$ & & AVIF $<5$ & Memenuhi kriteria \\
\hline
\end{tabular}

Sumber: data primer, diolah (2021)

Hasil output model fit indeks di atas telah terpenuhi yaitu dengan nilai APC sebesar 0.316 dan nilai ARS sebesar 0.221 telah signifikan karena nilai $\mathrm{P}<0.05$, serta nilai AVIF sebesar 1.212 lebih kecil dari 5 juga telah memenuhi kriteria. Sehingga untuk hasil evaluasi inner model dapat diterima.

\subsubsection{Nilai R Square $\left(\mathbf{R}^{2}\right)$}

Tabel 11

Goodness Fit Model

\begin{tabular}{|c|c|}
\hline Variabel & R-square \\
\hline AW & 0.36 \\
\hline PU & 0.07 \\
\hline
\end{tabular}

Sumber: data primer, diolah (2021) 
Pada uji kecocokan model (goodness fit model), salah satu keluaran yang dihasilnya adalah nilai $\mathrm{R}$-square $\left(\mathrm{R}^{2}\right)$. Nilai $\mathrm{R}$-square $\left(\mathrm{R}^{2}\right)$ dalam pengujian ini adalah sebesar 0,36 untuk pengaruh karakteristik kewirausahaan dan karakteristik individu dengan aktivitas wirausaha. Artinya sebesar 36\% variasi varibel eksogen yang digunakan dalam penelitian ini mampu menjelaskan variabel endogen, sisanya sebesar $64 \%$ dijelaskan oleh variabel lain diluar varibel eksogen yang digunakan dalam penelitian ini. Sedangkan nilai Rsquare $\left(\mathrm{R}^{2}\right)$ untuk uji pengaruh aktivitas wirausaha terhadap pertumbuhan usaha sebesar 7\%. Nilai ini dapat dikatakan rendah karena memiliki arti aktivitas wirausaha hanya mampu menjelaskan variasi sebesar 7\% terhadap pertumbuhan wirausaha. Rendahnya variasi ini dapat disebabkan oleh variabel eksogen yang digunakan hanya 1 variabel saja yaitu aktivitas wirausaha. Sehingga kemampuan variabel eksogen untuk menjelaskan variasi variabel endogen hanya sebesar $7 \%$.

\subsection{Pengujian Hipotesis}

Uji hipotesis dilakukan bertujuan untuk mengetahui apakah hipotesis yang diajukan dalam penelitian dapat terdukung atau tidak. Tingkat kepercayaan atas parameter populasi yang digunakan untuk mengambil keputusan dalam penelitian ini adalah sebesar 99\%, maka tingkat signifikansi yang digunakan sebesar $1 \%$. Hipotesis dinyatakan terdukung jika nilai p-value kurang dari sama dengan 1\%. Begitu juga sebaliknya jika p-value lebih dari $1 \%$, maka hipotesis yang diajukan tidak terdukung. Berikut adalah hasil analisis jalur menggunakan WarpPLS 7.0.

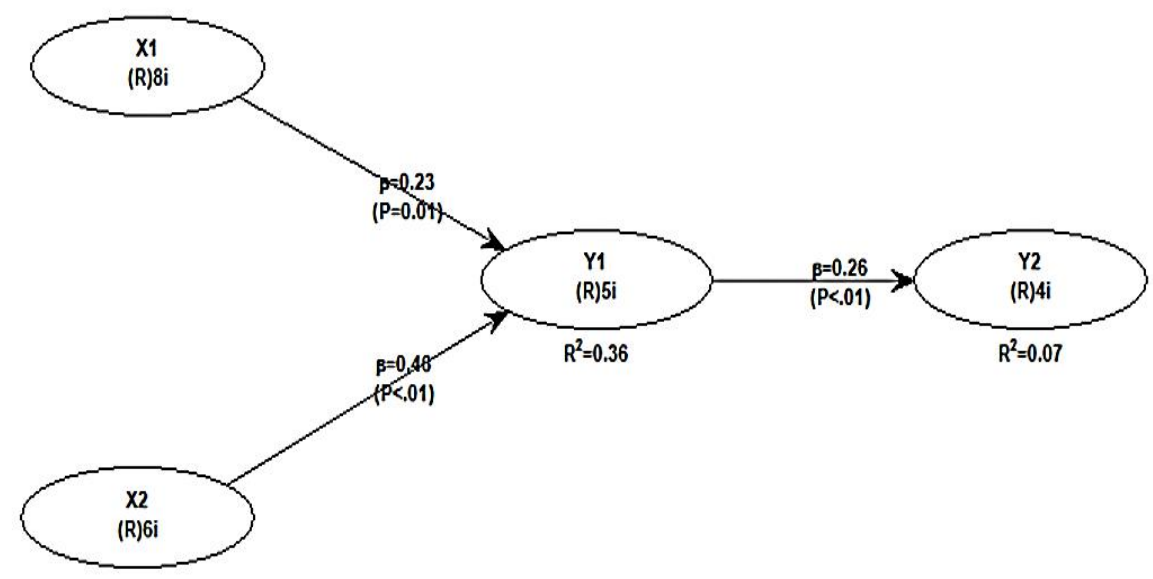

Gambar 2

Output Model WarpPLS 7.0

Tabel 12

Ringkasan Hasil Penelitian

\begin{tabular}{|c|c|c|c|c|c|}
\hline Hipotesis & Keterangan Jalur & Koefisien & P-Value & Ideal & Keterangan \\
\hline H1 & $\mathrm{X} 1(\mathrm{KK})-\mathrm{Y} 1(\mathrm{AW})$ & 0,23 & 0,01 & $\leq 0.01$ & Terdukung \\
\hline $\mathrm{H} 2$ & $\mathrm{X} 2(\mathrm{KI})-\mathrm{Y} 1(\mathrm{AW})$ & 0,46 & $<0,01$ & $\leq 0.01$ & Terdukung \\
\hline $\mathrm{H} 3$ & $\mathrm{Y} 1(\mathrm{AW})-\mathrm{Y} 2(\mathrm{PU})$ & 0.26 & $<0,01$ & $\leq 0.01$ & Terdukung \\
\hline
\end{tabular}

Sumber: data primer, diolah (2021) 


\subsection{Pembahasan}

Berdasarkan hasil analisis berikut diuraikan hasil pengujia hipotesis. Pertama, pengujian hipotesis 1 (H1): hasil analisis jalur menunjukkan bahwa nilai koefisien sebesar 0,23 dan nilai P-value sebesar 0.01. Dengan mempertimbangkan nilai tingkat signifikansi sebesar $1 \%$, maka hipotesis 1 terdukung. Artinya, karakteristik kewirausahaan bepergaruh terhadap aktivitas wirausaha. Sedangkan nilai koefisien regresi 0,23 menunjukan arah pengaruh positif antara karakteristik kewirausahaan dan aktivitas wirausaha. Hal ini membuktikan, seseorang yang memiliki ciri khas khusus wirausaha seperti locus of control, keberanian mengambil risiko, percaya diri, Need for Achievement, dan Innovativeness akan mampu menjalankan aktivitas usahanya dengan baik. Kedua, pengujian hipotesis $2(\mathrm{H} 2)$ : hasil analisis jalur menunjukkan bahwa nilai koefisien sebesar 0,46 dan nilai P-value sebesar kurang dari 0.01. Dengan mempertimbangkan nilai tingkat signifikansi sebesar 1\%, maka hipotesis 2 terdukung. Artinya, karakteristik individu berpegaruh terhadap aktivitas wirausaha. Sedangkan nilai koefisien regresi 0,46 menunjukkan arah pengaruh positif antara karakteristik individu dan aktivitas wirausaha. Karakteristik invidu berkaitan dengan ciri khas individu yang menjadi pembeda dengan individu lainnya. Studi ini membuktikan bahwa usia, tingkat pendidikan, dan pengalaman berusaha yang mumpuni akan menjadikan seorang wirausahawan mampu menjalankan aktivitas usaha dengan tujuan agar usahanya dapat terus tumbuh dan berkembang.

Untuk pengujian hipotesis 3 (H3): hasil analisis jalur menunjukkan bahwa nilai koefisien sebesar 0,26 dan nilai P-value sebesar kurang dari 0.01. Dengan mempertimbangkan nilai tingkat signifikansi sebesar 1\%, maka hipotesis 3 terdukung. Artinya, aktivitas wirausaha berpegaruh terhadap pertumbuhan usaha. Sedangkan nilai koefisien regresi 0,26 menunjukkan arah pengaruh positif antara aktivitas wirausaha dan pertumbuhan usaha. Jika wirausahawan mampu menjalankan aktivitas usahanya dengan baik yang dapat terlihat dari kegiatan produksi yang dilakukan serta memiliki daya saing yang kuat, maka usaha ini cenderung akan mengalami peningkatan dan tumbuh dan berkembang menjadi usaha yang skalanya lebih besar.

\section{Simpulan}

Dari hasil analisis data dan pembahsan dapat disimpulkan beberapa poin penting. Pertama, karakteristik kewirausahan merupakan ciri khas individu yang mendorong dirinya untuk menjadi seorang wirausahawan. Karaketristik kewirausahaan antara lain adalah motivasi menjadi seorang wirausahaa, keberanian mengambil risiko serta memiliki kemampuan untuk melakukan inovasi dalam berwirausaha. Studi ini membuktikan bahwa karakteristik kewirausahaan berpengaruh terhadap aktivitas wirausaha. Temuan ini selaras dengan hasil dari studi yang dilakukan oleh Sari, Septiowati dan Saputri (2021), Firnalista, Nofialdi, dan Azriani (2020) serta Al Farisi (2020) dimana menunjukkan bahwa karakteristik kewirausahaan juga berpengaruh positif terhadap aktivitas wirausahaan. Individu yang memiliki karakteristik kewirausahan yang kuat cenderung memiliki kemampuan untuk dapat memproduksi produk/jasa dengan baik sebagai salah satu kegiatan usaha, sehingga akan menciptakan daya saing usaha yang tinggi. Inilah yang menjadi alasan kuat bahwa ciri-ciri khas kewirausahaan berpengaruh terhadap aktivitas 
wirausaha. Kedua, Karakteristik individu adalah ciri khas atau sifat individu yang didapatkan sejak ia lahir. Oleh karena itu, ciri khas ini yang akan menjadi pembeda antar individu. Perbedaan ciri dan sifat ini akan terlihat dari cara masing-masing individu bersikap, merespon sesuatu dan berbicara. Dalam penelitian ini, karakteristik individu yang dimaksud adalah kematangan usia, pengalaman individu dalam menjalankan usaha, dan tingkat pendidiikan yang telah ditempuhnya.

Temuan dalam studi ini menunjukkan bahwa karakteristik individu terbukti berpengaruh terhadap aktivitas wirausaha. Hasil dari studi ini menunjukkan hasil yang sama dengan riset yang dilakukan oleh Sari, Septiowati dan Saputri (2021), Ikupolati, et. al (2017) dan Hendramotko (2021) yang membuktikan bahwa karakteristik personal mempengaruhi aktivitas wirausaha. Kematangan usia akan membuat individu lebih matang dalam mengambil keputusan. Sehingga individu yang memiliki kematangan usaha cenderung akan lebih berhati-hati dalam mengambil keputusan dalam menjalankan usahanya. Disisi lain, pengalaman individu akan mengasah insting usaha seorang wirausahawan. Oleh karena itu, seseorang yang memiliki pengalaman usaha memiliki kemampuan untuk menjalankan usahanya serta memiliki keberanian untuk bersaing dengan kompetitornya. Sedangkan latar belakang pendidikan menjadi salah satu bekal individu untuk menjadi seorang wirausahawan. Seseorang yang memiliki latar belakang pendidikan yang berkaitan dengan ilmu-ilmu bisnis akan cenderung menjalankan usahanya dengan analisis yang tepat dan tidak hanya berdasarkan insting semata.

Ketiga, aktivitas wirausaha adalah proses kegiatan usaha yang dijalankan seseorang yang telah memutuskan untuk menjadi seorang wirausahawan. Aktivitas itu terdiri dari proses memproduksi barang atau jasa untuk kegiatan usahanya serta diikuti dengan persaingan usaha yang dihadapinya. Dalam riset ini hasil pengujian menunjukkan bahwa aktivitas wirausaha berpengaruh terhadap pertumbuhan usaha. Temuan ini juga menguatkan hasil riset yang dilakukan oleh Sari, Septiowati dan Saputri (2021) yang menyatakan bahwa aktivitas wirausaha berpengaruh terhadap pertumbuhan usaha. Wirausahawan yang telah menjalankan aktivitas usahanya dengan baik dan maksimal akan mendapatkan hasil dari kegiatan usahanya tersebut. Usaha yang dijalankan pada akhirnya akan tumbuh dan berkembang. Pertumbuhan usaha akan terlihat dari meningkatnya omset penjualan, meningkatnya tenaga kerja yang dibu tuhkan untuk menjalankan proses usaha dan bertambahnya pelanggan yang sebagai indikator meningkatnya kepercayaan konsumen atas produk atau jasa yang ditawarkan oleh wirausahawan. Keemat, variasi variabel karakteristik kewirausahaan dan karakteristik individu dalam menjelaskan variabel aktivitas wirausaha adalah sebesar 36\%. Nilai ini menunjukkan bahwa variasi variabel eksogen terhadap variabel endogen tidaklah dominan.

Selanjutnya untuk simpulan terakhir bahwa variabel aktivitas wirausaha dalam menjelaskan pertumbuhan wirausaha sebesar 7\%. Nilai ini memang dapat dikatakan rendah dikarenakan hanya menggunakan satu variabel eksogen saja. Selain itu, studi ini dilaksanakan pada saat pendemi Covid-19 berlangsung yaitu pada tahun 2020. Sehingga aktivitas wirausaha yang dijalankan oleh pelaku usaha UMKM bakery dan kue di 
kabupaten Bantul mengalami hambatan untuk melaksanakan aktivitas usahanya. PSBB (Pembatasan Sosial Berskala Besar) menjadi pukul besar bagi pelaku usaha karena jam operasional toko harus dibatasi, bahkan ada beberapa toko yang akhirnya memutuskan untuk menutup sementara usahanya.

Hasil dari studi ini juga memberikan beberapa saran serta rekomendasi. Pertama, adanya pandemi Covid-19 tidak menyurutkan semangat serta motivasi wirausahawan untuk menjalankan aktvitas wirausahanya. Oleh karena itu, para pelaku usaha UMKM bakery dan kue di kabupaten Bantul harus senantiasa mengasah kemampuannya untuk lebih mempertajam karakteristik kewirausahaan dan karakteristik individu sehingga dapat menjalankan aktivitas wirausahanya dengan optimal. Kedua, pertumbuhan usaha akan tercapai jika aktivitas produksi yang dilakukan berjalan sesuai target yang telah ditentukan serta diikuti dengan daya saing yang dimiliki mampu berkompetisi dengan kompetitornya. Dengan mempertimbangkan kondisi pandemi Covid-19 yang masih berlangsung, setiap pelaku usaha harus memiliki strategi pivot business dengan memanfaatkan teknologi informasi agar dapat memenangkan persaingan dalam kompetisi usahanya.

Selanjutnya untuk rekomendasi terakhir bahwa dengan mempertimbangkan nilai Rsquare $\left(\mathrm{R}^{2}\right)$ yang hanya menunjukkan nilai yang tidak terlalu besar dalam meenjelaskan variasi varibel eksogen terhadap variabel endogen. Maka, peneliti menyarankan bagi studi selanjutnya untuk menambahkan variabel eksogen seperti intensi kewirausahaan yang menggambarkan niat seseorang untuk memilih profesi untuk menjadi seorang wirausahawan. Studi selanjutnya juga dapat mempertimbangkan aktivitas wirausaha sebagai variabel yang memoderasi aktivitas kewirausahaan dan aktivitas individu terhadap pertumbuhan usaha.

\section{Referensi}

Abdillah, Willy dan Jogiyanto Hartono. (2016). Partial Least Square (PLS): Alternatif Structural Equation Modeling (SEM) dalam Penelitian Bisnis. Yogyakarta: Andi.

Al Farisi, Yasir. (2020). Effects of Entrepreneurial Characteristics on the Success of SMEs in the Saudi Arabian Market. (Thesis Master, Western Sydney University, 2020).

Diakses

dari https://researchdirect.westernsydney.edu.au/islandora/object/uws:59868/

Atmaja, Ahmad Tri., \& Margunani. (2016). Pengaruh Pendidikan Kewirausahaan dan Aktivitas Wirausaha Terhadap Minat Berwirausaha Mahasiswa Universitas Negeri Semarang. Economic Education Analysis Journal,5(3), pp.774-787. Diakses dari https://journal.unnes.ac.id/sju/index.php/eeaj/article/view/13578

Badan Pusat Statistik (BPS). 5 November 2020. "Berita Resmi Statistik", diakses pada tanggal $10 \quad$ November $2020 . \quad$ Dari https://www.bps.go.id/website/materi_ind/materiBrsInd-20201105120056.pdf

Diandra, D., \& Azmy, A. (2020). Understanding Definition of Entrepreneurship. International Journal of Management, Accounting and Economics, 7(5), 235- 241. Diakses

dari https://www.ijmae.com/article_114343_cf371dc3f6f0acc2fcbbb1bb8bfa00f8.pdf 
Farrukh, M., Khan, A. A., Khan, M. S., Ramzani, S. R., \& Soladoye, B. S. A. (2017). "Entrepreneurial Intentions: The Role of Family Factors, Personality Traits And Self- Efficacy". World Journal of Entrepreneurship, Management and Sustainable Development, 13(4). https://doi.org/10.1108/WJEMSD-03-2017-0018

Firnalista, N., Nofialdi, \& Azriani, Z. (2020). Impact of Entrepreneurial Characteristics and Access to Credit on Business Performance of Small Business (Case: Brown Sugar Processing in Agam District). Indonesian Journal of Agricultural Research, 3(1), 56 - 64. https://doi.org/10.32734/injar.v3i1.4289

Ghina, Astri dan Fanji Ramadhan. (2016). Analisis Karakteristik Kewirausahaan Dan Minat Kewirausahaan Pada Mahasiswa Fakultas Industri Kreatif Universitas Telkom Angkatan 2012-2013. E-Proceeding of Management, 4(3). Hal 2172. Diakses dari https://openlibrarypublications.telkomuniversity.ac.id/index.php/management/arti cle/view/4881

Hendratmoko. (2021). Faktor-Faktor Yang Mempengaruhi Kinerja UMKMDi Indonesia. Jurnal Orientasi Bisnis dan Entrepreneurship, 2(1), 50-65. https://doi.org/10.33476/jobs.v2i1.1782.

Hisrich, R. D., Peters, M. P., dan Shepherd, D. A. (2017). Entrepreneurship (tenth edition) New York: McGraw-Hill.

Ikupolati, Ikupolati., Olatunle, M., Medubi., dan Ikupolati, Alexander. (2017). Impact Of Entrepreneurs Individual Characteristics on The Performance of Small and Medium Enterprises (Smes) In Nigeria. KASU Journal of Management Sciences, 8(1), 3546.

Diakses

dari http://repository.futminna.edu.ng:8080/jspui/handle/123456789/7526

Irwan, dan Adam, K. (2015). Metode Partial Least Square (PLS) dan Terapannya (Studi Kasus: Analisis Kepuasan Pelanggan Terhadap Layanan Pdam Unit Camming Kab. Bone). Jurnal Teknosains. 9(1). https://doi.org/10.24252/teknosains.v9i1.1856

Robbins, S. P. dan Coulter, M. (2016). Management. Pearson Education Limited 2016. 13th Edition, ISBN 978-0-13-391029-2

Sari, N. M., Suwarsinah, H., dan Baga, L. (2016). Pengaruh Karakteristik Kewirausahaan terhadap Kinerja Usaha Mikro, Kecil dan Menengah (UMKM) Gula Aren di Kabupaten Lombok Barat. Jurnal Penyuluhan, $12 \quad$ (1). https://doi.org/10.25015/penyuluhan.v12i1.11320

Sari, Silvia, Septiowati, Rini dan Sevty Wahiddirani Saputri. (2021). Pengaruh Aktivitas Kewirausahaan Terhadap Pertumbuhan Usaha Pengolahan Sampah Di Bank Sampah Sawangan, Depok. Jurnal Agribisnis Indonesia, 9 (2), 154-165. https://doi.org/10.29244/jai.2021.9.2.154-165

Sarwoko, Endi dan Christea Frisdiantara (2016). Growth Determinants of Small Medium Enterprises (SMEs). Universal Journal of Management, 4(1), 36 - 41. DOI: 10.13189/ujm.2016.040105.

Sholihin, Mahfud dan Dwi Ratmono. (2021). Analisis SEM-PLS dengan WarpPLS 7.0. Yogyakarta: Penerbit ANDI. 
Subramani, Joghee. (2020). Concept of Entrepreneurs and Entrepreneurship- A Critical Review. International Journal of Innovative Science and Research Technology. 5 (5).

Diakses dari https://www.ijisrt.com/assets/upload/files/IJISRT20MAY187_(1).pdf

Sujarweni, V. Wiratna. (2014). Metode Penelitian: Lengkap, Praktis, dan Mudah Dipahami. Yogyakarta: Pustaka Baru Press.

Wijaya, Andy, Dkk. (2020). Manajemen Operasi Produksi. Yayasan Kita Menulis. Web: kitamenulis.id.

www.cnnindonesia.com. 15 November 2017. Diakses pada 15 Februari 2020. Kemenkop UKM: 3,79 Juta UMKM Sudah Go Online. Dari https://www.cnnindonesia.com/ekonomi/20171115161037-78-255819/kemenkopukm-379-juta-umkm-sudah-go-online/.

Zainal, V.R., Ramly, M., Mutis, T., dan Arafah, W. (2018). Manajemen Sumber Daya Manusia untuk Perusahaan dari Teori ke Praktik. Edisi Ketiga. Jakarta: Raja Grafindo Persada. 